\title{
EXPANSION OF AGRICULTURAL ZAKAT REVENUE IN MALAYSIA ON THE BASIS OF THE CURRENT MASLAHAH
}

\author{
Muhamad Firdaus Ab Rahman*; Hussein`Azeemi Abdullah \\ Thaidi*; Ahmad Syukran Baharuddin*; Azman Ab Rahman*; \\ Siti Farahiyah Ab Rahim** \\ * Universiti Sains Islam Malaysia (USIM); ** University of Glasgow, \\ Scotland \\ email:mfirdaus.rahman@usim.edu.my
}

\section{Abstract}

The reality concerning the agricultural zakat in Malaysia only impose the zakah on the paddy crops based solely on the opinion of Imam Shafi i rather than an opinion of other scholars. This paper aims to critically examine the agricultural zakat in Islam based on Malaysian context and analyse the transformation of expanding the agricultural zakat based on the objective of Shariah. A qualitative methodology was employed to analyse the data through inductive, deductive, comparative and field research. As for the field research, the study has conducted semi-structured interviews with the Zakat Corporation, Islamic Religious Council and Muftis Department in the selected states in Malaysia, namely: Selangor, Penang, Terengganu and Sarawak. The finding demonstrated that the revenue of the agricultural-based zakat could be expanded according to the view held by Imam Hanafi and its benefit to the current agricultural economy. Thus, this paperproposes that every State's Zakat Corporations and Islamic Religious Councils in Malaysia should reassess the existing ruling and legal framework of agricultural zakat in order to realize its revenue expansion as an effective solution for the current zakat collection. [Realitas rakat pertanian di Malaysia lebih mengutamakan qaul Imam Shafi i dibandingkan dengan qaul-qaul mazhab lain. Pengelolaan zakat 
di Malaysia hanya dikenakan pada zakat pertanian dan terbatas kepada makanan pokok, yaitu padi. Artikel ini bertujuan untuk. menganalisis secara kritis zakat pertanian dalam konteks Malaysia serta mengkeaji transformasi isu meluaskan zakat pertanian kepada tanaman selain padi berdasarkan maqasid syari'ah. Kajian ini menggunakan metode kualitatif, dimana analisis data menggunakan kaedah induktif, deskriptif, dan komparatif. Kajian lapangan juga dilakukan dalam bentuk wawancara dengan Jabatan Mufti Negeri dan Baitulmal Negeri di Malaysia; seperti Selangor, Pulau Pinang, Perlis, Terengganu dan Sarawak. Hasil kajian menunjukkan bahwa basil zakat pertanian dapat diperluas berdasarkan pendapat Imam Abu Hanifah yang lebih sesuai dengan maslahah ekonomi pertanian saat ini di Malaysia. Dengan demikian, studi ini mengusulkan bahwa lembaga zakat setiap negeri dan Dewan Agama Islam di Malaysia harus mengkaji kembali kerangka bukum zakat pertanian yang ada dalam rangka merealisasikan ekspansi penghasilannya sebagai solusi efektif untuk pengumpulan rakat saat ini.]

Keywords: agricultural zakat, expansion of revenue, objectives of shariah, flexibility, Malaysia

\section{A. Introduction}

Agricultural industry in Malaysia today has shown an impressive growth in the surge of globalization and technology, especially with the emergence of commercial agriculture of various crops, a condition which was originally only revolved on paddy plantations which proved to be a very lucrative business to Malaysian farmers. As the result, various types of crops have given a very good return, exemplified by commercial agriculture of palm, rubber farming, and coconut farming. Therefore, there is an allocation of Islamic law regarding the obligatory zakat-paying, namely the existence of wealth also that it can benefit the poor, ${ }^{1}$ therefore a law transformation is nothing but essential-it was once for self-sustenance but now through time, it has undergone a shift to being commercialized.

1 Mohd Rifqi Myibbin et al., "Zakat Pertanian dalam Konteks Malaysia: Satu Kajian dan Penilaian Semula", in Islam: Past, Present and Future, ed. by Ahmad Sunawari, Long Jaffary, and Awang Kamaruddin Salleh (Bangi: Universiti Kebangsaan Malaysia, 2004), p. 758. 
The Malaysian reality reveals that agricultural zakat have mainly focused on paddy plantation that can be said to be the traditional source of zakat. In logic, if paddy farmers were so adamant into paying the zakat, why would not be the rubber plantation and oil palm plantation owners, who normally have higher income? Currently, the effort to seek for a new resource of zakat has been intensified by relevant bodies as evident from the execution of the zakat of income. This obligation is based on its great amount, exceeding the limit of zakat-compulsory for currency, therefore using these prerequisites to make zakat-paying compulsory is used towards commercial agriculture that is undoubtedly beneficial to ummah.

The distinctive specification of the Islamic law is very much based on the flexibility of the law in question. History has proven that there are a lot of figh issues that vary in their laws, taking into consideration various primary factors of current and local values. It takes credit on its philosophy of adapting the law to achieve the purpose of Sharia (maqasid syari'ab) which is to make provision for the welfare of the people-known as tahqiq masalih al-ibad, maintaining this noble intention and safeguarding it from any damage. This safeguarding act centralizes on the essential (al-daruriyyat), the complimentary (al-bajiyyat) and the embellishments (al-tabsiniyyat) and also maintaining these five essential elements of the Shariah (al-daruriyyat al-Khams), namely; prevention of religion (bifz $u$ addin), prevention of life (bifzu an-nafs), prevention of intellect (bifž al-'aql), prevention of progeny (bifz $u$ an-nasb) and prevention of property (bif z $u$ al-mal). In the context of adding a new resource for zakat, the agricultural zakat has stood in prominence in safeguarding the property (bifzu al-mal) and the Muslim economy particularly in Malaysia. ${ }^{2}$

Responding to this, a transformation of agricultural zakat in Malaysia based on the core of Islamic law namely maqasid syari'ah in redefining the concept, theory, laws and Islamic-based approach, as well as the adaptability of laws based on current and local values. This study will examine the obligations behind paying agricultural zakat other than

${ }^{2}$ Hasanah Binti Abd Khafidz, "Asnaf Lapan: Kesan Nilai Semasa dan Setempat dalam Pentafsirannya di Malaysia", PhD. Dissertation (Kuala Lumpur: University of Malaya, 2006), p. 2; Rahmatina A. Kasri, "Maqasid al-Shariah and Performance of Zakah Institutions", Kyoto Bulletin of Islamic Area Studies, vol. 9 (2016), p. 24. 
paddy plantation, also debate on the issue of the estimation of the paddy zakat in Malaysia. All these issues are connected to maqasid syari'ab that serves as the basic requirement of Islamic law to maintain the benefits for beneficiaries (asnaf) so that the law of zakat is more dynamic and flexible.

\section{B. Agricultural Zakat in Malaysia: The Regulation and Its Islamic Principle}

The agriculture in Malaysia has progressed since early independence of 1957 and contributed to the national economic growth with the National Gross Domestic Product (GDP) totalling 46\%. ${ }^{3}$ Malaysian crops have developed up until now comprising of the main crops, wheat, fruit crops, vegetable crops, spices, coconut, and dry crops.

The Malaysian experience in the collection of agricultural zakat only concentrates on the paddy, holding on to the Shafi i sectarian belief that crops zakat is only imposed on staple food $(q u t)$, any agricultural yield that is fulfilling under normal conditions, cultivated by human, can be kept for long and can be dried. ${ }^{4}$ This sectarian view does not take into account other agricultural yields such as the main crops that are more lucrative like palm oil, rubber and coconut as based on the hadith by Mu`az Ibn Jabal.

"Upon which is poured by the sky and the rain, drains, wells also the natural springs comes in ten percent and on what is poured by the animal five percent. These are on the fruits, wheat and cereal seeds. But for the melon, cucumber, pomegranate, shoots and vegetables are exempted by Rasulullah p.b.u.h." 5

3 Abi Musa Asa'ari Mohamed Nor, "Transformasi dalam Sektor Pertanian dan Industri Asas Tani", presented at the Halatuju Sektor Pertanian dan Industri asas Tani (Selangor: Kementerian Pertanian dan Industri Asas Tani, 12 Aug 2004), p. 2.

4 Muhammad ibn Idris al-Shafi'i, Al-Umm, vol. 2 (Beirut: Dar al-Ma arif, 1973),

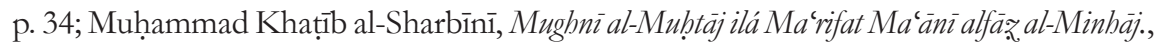
vol. 2 (Beirut: Dār al-Kutub al-'Ilmīyah, 2009), p. 381; Jalaluddin Abd Rahman alSayuti, Al-Ashbah wa al-Nazair fi Qawa'id wa Furu' Fiqh al-Shafi'iyah (Riyadh: Maktabah Nazar Mustafha al-Baz, 1997), p. 471; Muhamad Firdaus Ab Rahman and Muhammad Amanullah, "The Implementation of Temporary Endowment in Kuwait", Al-jami'ah: Journal of Islamic Studies, vol. 54, no. 2 (2016), pp. 480-1.

5 Aḥmad Ibn-al-Husain al-Baihaqī, As- Sunan al-Kubrā, vol. 4 (Beirut: Dār alKutub al-'Ilmìya, 1994). Kitab al-Zakat, "Bab La Syaiun Fi al-Thamar Hatta Yabluq Kullu Sinfi Minha Khamsan Awsuq Fayakun Fi Ma Balaqa Minhu Khamsah Awsuq 
In Malaysia, the Shariah Law Consultation Commitee has stipulated that the main commodity crops such as palm oil, coconut, rubber and others are not made compulsory for zakat. ${ }^{6}$ The question arose wether the crops that are to be imposed for zakat only limited to staple food in one particular place only? Are the views of Shafi i sect the most valid? Is adhering to the Shafi $i$ sect totally fulfills the purpose of the Islamic laws and regulations of zakat, especially in Malaysia?

Al-Qardawi ${ }^{7}$ has expressed some criticisms on the issue of the limited yield of the agriculture by stating that:

"It is not a wise move to make compulsory zakat on the wheat planters but only dismissing the orange and apple cultivators, where both are Earth's natural resources."

Based on the commentary above, it demonstrates the principle of al-Qardawi ${ }^{8}$ in regard of the expansion of the agricultural zakat yield by holding on to the views of Abu Hanifah which obligates the agricultural zakat onto all crops based on the generalized nas from a verse of Qur'an 2: 267 and 6: 141.

The same goes with the hadith as told by Ibn 'Umar which is more in tandem with public interest (maslahab ammah) and the current agricultural economy, as such:

"What is showered by the sky or the springs or container ten percent, and on what is showered by the energy five percent."

If al-Qardawi's views are applied to commercial crops such as palm oil, rubber and coconut they can be imposed with agricultural zakat Sadaqah", no. Hadith 7268. Al-Nawawi states that this hadith is mursal. Meanwhile in the tale of Daruqutni from Mu'az bin the hadith sanad is da'if because Muhamad bin Abdullah al-'Azrami in the sanad has been dismissed.

6 “Kelapa Sawit Kena Zakat Tanaman?”, al-abkam.net (24 Sep 2008), http:// www.al-ahkam.net/home/content/sj-11-0218-kelapa-sawit-kena-zakat-tanaman, accessed 30 Dec 2018.

7 Yusuf Al Qardawi, Fiqh al Zakah (Beirut: Muassasah al-Risalah, 1997), p. 355.

8 Al-Qardawi holds on to the views of Imam Hanafi as he opines that the views are the most valid.

9 Muhammad ibn Ismācîl al Bukhari, Sahih Al-Bukhari (Damascus: Dār ibn Kathīr, 1993). Kitab al-Zakat, 'Bab Al-'Usyr Fi Ma Yuskha Min Ma' as-Sama' Wa Bil Ma' Al-Jari”, no Hadith 1483. Hadith sahih. Ahmad bin 'Ali Hajar Al-asqalani, Fath al-Bari bi-Syarah Sabih al-Bukhari, vol. 3 (Beirut: Dar al-fikr, 1993), p. 346. 
when surpassing the, then it will be able to enhance and to strenghten the rate of collection of the agircultural zakat and even make stronger the economy of the Muslim community especially those qualified to receive zakat (asnaf).

Issues regarding the expansion of the yield of agricultural zakat had been articulated in the reigning era of Caliph 'Umar al-Khattab. The Caliph had made the effort in expanding his interpretation of the agricultural zakat towards vegetables and legumes such as nuts ('adas), white nuts (bumus), cotton (kutniyyah) and pomegranate is to be imposed with zakat. ${ }^{10} \mathrm{He}$ also imposes zakat on horses, as maslahab when using the horses in his era is commercialised as compared to its use in the era of the Prophet is only limited to agriculture and transportation. The question is would this oppose the hadith by Abi Hurairah ${ }^{11}$ who does not make compulsory this kind of zakat on horses? 'Umar's ijtibad in his expansion of agricultural zakat that centers on the local and current maslahah, does not out aside or abandon the nas of Qur'an even hadith. Thus, based on the current and local maslahah a law will not be rigid and can be altered based on Islamic legal maxim (qawa id fiqhiab) "Laws (fatwa) can change due to the change of time, place and environment". ${ }^{12}$

\section{Debate on Definition and its Prerequisite of Agricultural Zakat in Malaysia}

In Malaysia, all states impose zakat solely on paddy yield which is based on Imam al-Shafi $i$ sect view that zakat is only imposed on the

10 Musa Ahmad, Arifin Md Salleh, and Abdullah Said, "Penerokaan Sumber Baru Zakat di Malaysia", presented at the Persidangan Zakat dan Cukai Peringkat Kebangsaan (Selangor, 22 Apr 2007), pp. 2-4. See Nūr al-Dīn Alī ibn Abī Bakr Haythamī, Majma' aq-Zawaid wa Manba' al-Fawaid (Cairo: Maktabat al-Qudsī, 1994). Kitab al-Zakat, "Bab Zakat al-Hubub", no. Hadith 4399, al-Tabrani states that in the book of al-Kabir rijal hadith thiqat and sahih.

11 Umar's ijtihad seemingly opposes the hadith by Abi Hurairah, Prophet Muhammad said: "Zakat is not made compulsory on the horses and slaves". Narrated by Bukhari, Sabih Al-Bukhari. Kitab al-Zakat, "Bab Laisa `Ala al-Muslim Fi Farasihi Wa Qulamihi Sadaqah", no Hadith 1394. Hadith sahih.

12 Muhammad ibn Abī Bakr Ibn Qayyim al-Jawzīyah, I Yam al-Muwaqqi in ‘an Rabb al-'Alamin, ed. by Muhammad Muhyu al-Din 'Abd 'Aziz (Beirut: Dar al-Fikr, 1977), p. 14. 
staple food of a particular region, which can be stored for a long period and can be dried. However, no specific definition is made in all states, due to the fact that the existing interpretation on crop is too general based on a verse 227 in Qur'an, 2: 267 and the view of Shafi 'i's school of thought alone. For instance, Selangor Zakat Board (LZS) defines agricultural zakat as:

"A form of zakat imposed on a hearty staple food upon a state that fulfilled the nisab (the minimum amount of property or wealth that must be owned by a muslim before he/she is obligated for zakat). Crops yield that is compulsory for zakat includes staple food cereals that can be of a hearty meal and could last for a long period if stored such as paddy, dates, corn, wheat, et cetera. Staple food for Malaysian is rice and it is obtained from paddy." 13

Zakat Management Centre, Penang Islamic Religious Council (MAINPP PUZ) and Baitulmal of Perlis Islamic Religion and Malay Customs Council (MAIPs) add another condition for the crop, namely "of which cultivated by human"14 and "on a piece of land belonging to them, being rented or as such" 15 in their version of crop zakat. On the other hand, Sarawak Baitulmal Fund (TBS) defines it as part of "net income" and "beneficial agricultural yield". ${ }^{16}$ We argues that an interpretation is normally closely related to its implementation, for example in Sarawak, the term 'net income' is used because TBS permits the deduction of operational costs before a zakat is made compulsory, compared to Selangor which imposes it on gross value. ${ }^{17}$ However the term "beneficial agricultural yield" has opened up the maslahah dimension in extending

13 Lembaga Zakat Selangor, "Kiraan Zakat Padi”, Lembaga Zakat Selangor (2018), https://www.zakatselangor.com.my/keputusan-syariah-zakat/kiraan-zakat-padi/, accessed 14 Nov 2018.

14 Zakat Management Center of Penang, "Zakat Pertanian”, Zakat Pulau Pinang, http://www.zakatpenang.com/zpp/index.php/2013-06-30-10-54-31/jenis-zakat/ zakat-pertanian, accessed 2 Sep 2017.

15 Majelis Agama dan Istiadat Melayu Perlis, Buku Panduan Zakat (Perlis: Baitulmal MAIPs), p. 17.

16 Tabung Baitulmal Sarawak, "Tanam-Tanaman", Tabung Baitulmal Sarawak, https://www.tbs.org.my/www/?page=97, accessed 31 Aug 2017.

17 Muhamad Firdaus Abdul Rahman et al., "The Inconsistency Of Assessing Agricultural Zakat”, Global Journal Al Thaqafah, vol. 4, no. 1 (2014), pp. 20-1.. 
the crop to other crops apart from paddy which bear considerable profit and benefits to the beneficiaries.

There were issues surfaced at the Baitulmal of MAIPs regarding the definition of agricultural zakat, since according to the decision (fatwa), agricultural zakat is categorized under zakat for salary or income on the basis that it is also being yielded at a particular period of time and season, ${ }^{18}$ and this is contrary to the definition issued by the Baitulmal of Perlis. ${ }^{19}$ Based on this diverse nature of the zakat definition, it is very appropriate for relevant authorities in the state to develop a system of guidelines for interpreting terms for each type of property and asnafs for zakat so that its implementation is in line with the prescribed terminologies. ${ }^{20}$

\section{Assessment on the Arguments and Opinions of Fuqaha of Mazhab}

There are some differences in terms of understanding each maşhab, because most Islamic scholars (fuqaba) are influenced with external or internal factors such as the influence of economic, social, local and current environment. We considers that the view of Abu Hanifah is based on the assertion made by Daud al-Zahiri, Nakha'i, 'Umar bin 'Abdul 'Aziz, Mujahid and Hammad bin Sulaiman in making agricultural zakat compulsory for all the crops based on the generality of the nas and hadith, except for crops that had been agreed upon to be non-obligatory for zakat, namely; grass, firewood and sugar cane.

Abu Hanifah's opinion was based on a hadith narrated by Imam al-Bukhari: "There is a tenth ("ushr) on land watered by the sky or springs or running springs. There is half an "ushr $(5 \%)$ on land which is irrigated". ${ }^{21}$

18 Majelis Agama Islam dan Istiadat Melayu Perlis, "Zakat Tanaman”, Majlis Agama dan Istiadat Melayu Perlis, https:/ / www.maips.gov.my/index.php, accessed 11 Sep 2018; SS Mufti Jabatan Mufti Negeri Perlis, Kompilasi Keputusan Fatwa (Perlis: Jabatan Mufti Negeri Perlis, 2018), pp. 4-10.

19 Majelis Agama dan Istiadat Melayu Perlis, Buku Panduan Zakat, pp. 17-8.

20 Suhaili Sarif, Nor Azzah Kamri, and Azian Madun, "The Impact of Malaysian Islamic Revivalism on Zakat Administration", International Journal of Nusantara Islam, vol. 1, no. 1 (2013), pp. 40-1.

21 Bukhari, Sahih Al-Bukhari. Kitab al-Zakat, Chapter "Al-'Usyr Fi Ma Yuskha Min Ma' as-Sama' Wa Bil Ma' Al-Jari”, Hadith No. 1483. Hajar Al-Asqalani, Fath al-Bari bi-Syarah Sabih al-Bukhari, 3: 346. Hadith sahih. 
The syllable ' $m a$ ' (on what) in this sentence which means 'alladbi' is a general syllable, hence the method of qiyas is not appropriate to be used in this case, since it opposes the general syllable that should not be specific. For those who employ the method of qiyas, the make a general syllable to be specific with making zakat an obligation only to hearty crops, namely crops that serve as staple food (aqwat) only, as what being practiced by Shafi i sect.

Al-Qardawi supports Abu Hanifah's view and argues that it is appropriate with the maqasid and the main objective of zakat onto crop's yields. Objective of zakat will not be achieved and unable to guarantees better quality of life for the zakat payer if zakat is only made compulsory solely to paddy cultivators, while other commercial farmers not bound to this responsibility. ${ }^{22}$ Even though most fuqaha have stressed that the nas of al-Qur'an employed by this mazhab is too general, if being compared to arguments used by other mazhabs, this particular opinion is the safest of all and the most sabih to be applied to the current agricultural situation.

Al-Qardawi has analysed the view of Ibnu 'Umar and Salaf Ulama on hadith that states that zakat on crop is only made compulsory upon four types of crops, not a single badith among the analysed badith that is free from defects. ${ }^{23}$ In al-Zawa'id, hadith of 'Abdullah Ibn 'Amru narrated by Ibn Majah is considered to be weak since there are too many narrators whose hadiths are rejected such as Muhammad Ibn 'Ubaidillah. ${ }^{24}$ Meanwhile, the problem with hadith mursal's narration is like hadith narrated by Mu az Ibn Jabal. ${ }^{25}$ Ibnu Malik did not miss out

22 Al Qardawi, Figh al Zakah, p. 355; Mahyuddin Haji Abu Bakar and Abdullah Haji Abd.Ghani, "Towards Achieving the Quality of Life in the Management of Zakat Distribution to the Rightful Recipients (The Poor and Needy)", International Journal of Business and Social Science, vol. 2, no. 4 (2011), pp. 238-41.

23 Al Qardawi, Fiqh al Zakah, pp. 337-41.

24 Narration of Ibn Majah, Kitab al-Zakat, "Bab Sanna Rasulullah p.b.u.h az-Zakat Fi Hazihi al-Khamsah", no Hadith 1815. Muhammad ibn Yazīd Ibn Mājah, Sunan Ibn Mâjah (Cairo: Dar Ibn al-Jawzi, 2011), p. 580. In al-Zawaid the sanad is weak since Muhamad bin Ubaidullah was a khazraji. Imam Ahmad stated that many people abandoned his hadiths. Al-Hakim stated that this hadith is matruk (abandoned) and this opinion is supported by scholars of hadith.

25 Narration of Haythamī, Majma' az-Zawaid wa Manba' al-Fawaid, v. 4399; al-Amīr Muḥammad Ibn-Ismā'îl al-Jamanī aṣ-Ṣan'ānī, Subul as-Salām, vol. 2 (Cairo: alMaktaba at-Tighārijja al-Kubra, 1953), pp. 132-3. Abu Zar'ah stated that this hadith 
in giving criticism, it is quite impossible when limitation only occur to that four types of food, possibly, the limitation was meant to be for a certain period of time and not absolute in nature. ${ }^{26}$ If the truth of these opinions are observed, then the major staple food in Malaysia will not be subjected to zakat, since paddy does not fall under any of the four categories of food formulated since the time of Madinah, and the same applies to crops in other countries which could be different in terms of the climate, weather and soil fertility.

On the other hand, assessment on Imam Malik and Imam Shafi i's opinion that described the features of the crops subjected to zakat, namely crops can be stored for a long time, can be dried and also serve as staple food. Arguments used by this group were also being challenged, for example hadith of $\mathrm{Mu}{ }^{\prime} \mathrm{z}^{27}$ narrated by al-Baihaqi that is mursal even though it can be backed by hadith of the same type. Ibnu 'Arabi was among fuqaha from the Maliki sect who disagreed with this group, in fact, he supported Abu Hanifah's opinion more. Ibnu `Arabi commented on his reasons by stating that the Hanafi sect in this case is the most relevant and it concurs with maqasid shariah which accounts for the poor and also clearly expressing gratitude upon blessing bestowed by Allah as compared to other sects.

Furthermore, Imam Ahmad's view that zakat is compulsory on fruits that can be measured based on a hadith by Prophet Muhammad, "There is no zakat on anything less than five wasaq" ${ }^{28}$ is inaccurate. This is because the real meaning and objective of this hadith is in determining the nisab for zakat which encompasses all types of crops; fruits and

is Mursal.

26 Șan'ānī, Subul as-Salām, 2: 338.

${ }^{27}$ Narration of Baihaqī, As- Sunan al-Kubrā, 4: 7268. Kitab al-Zakat, "Bab La Syaiun Fi al-Thamar Hatta Yabluq Kullu Sinfi Minha Khamsan Awsuq Fayakun Fi Ma Balaqa Minhu Khamsah Awsuq Sadaqah.” Al-Nawawi stated that this hadith to be mursal. While in Daruqutni's narration from Mu'az bin Jabal, the sanad for the hadith is da'if since Muhamad bin Abdullah al-'Azrami is ignored in its sanad.

28 Narration of Muslim, Kitab al-Zakat, "Bab Ma Fihi al-'Usyr al-Nisfu al-'Usyr", no.Hadith 979. Imam Muslim ibn al-Hajjaj al-Naysaburi, Saḅị̧ Muslim (Liechtenstein: Jam'īyat al-Maknaz al-Islāmī, 2000), p. 475. Al-Nasai's Narration, Kitab al-Zakat, Zakat al-Hubub Chapter, Hadith No. 2485. Aḥmad ibn Shu'ayb Nasā'̄, Sunan al-Nasā̄ù, vol. 5 (Beirut: Dar al-Ma'rifah, 1992), p. 41. 
grains alike. $^{29}$

The same applies to a hadith in which Prophet ordered that grain to be taken out of grain ${ }^{30}$ which depicts no other meaning except a general statement which means grains are also subjected to zakat.

Similarly, in regard of a hadith which states that zakat is not compulsory on vegetables, ${ }^{31}$ Ibn al-Humam also denies the validity of that hadith. ${ }^{32}$

We have an assessment that the generality of arguments held by Hanafiyah sect reflects the flexibility of Islamic law that can be implemented differently due to difference in time, location, situation and also the custom ( urf) so that it will not burden the society is the fact that its method and form had been determined in detail. The need to be practical and flexible in Islam is supported by Nasir and Abdullah. ${ }^{33}$ This view is suitable with current growth in agricultural economy in Malaysia. Paddy crop is no longer viewed as profitable, yet in fact is now viewed as the crop for the self-sufficiency of the farmers compared to

29 Șan'ānī, Subul as-Salām, 2: 338-9.

30 Narration of al-Baihaqi, Kitab al-Zakat, "Bab La Yuaddi 'An Malihi Fima Wajaba 'Alaihi Illa Ma Wajaba 'Alaihi”, no Hadith 7197. Baihaqī, As- Sunan al-Kubrā. Sanad is considered as hasan and its rijal regarded as thiqah. Abu Daud's Narration, Kitab al-Zakat, "Bab Sadaqah al-Zar", no Hadith 1599. Abū Dā’ūd Sulaymān ibn al-Ash'ath al-Sijistānī, Sunan Abu Dawud (Beirut: Mu’assasat al-Kutub al-Thaqafiyah, 1988), p. 503. Sanad for this hadith is da'if due to incomplete sanad.

31 Narration of Al-Daruqutni, Kitab al-Zakat, "Bab Laisa Fi Al-Khadrawat Sadaqah”, no Hadith 1884. 'Alī ibn 'Umar Dāraquțni, Sunan al-Dāraquṭni, vol. 2 Jeddah: Dār al-Andalus al-Khaḍrā’ lil-Nashr wa-al-Tawzī', 2000), p. 96. Ibn Humam stated that vegetables such as riyahin, aurad, nuts, cucumber, melons, eggplant and such are not considered staple food since zakat is only subjected upon staple food. See Alī ibn Sulțān Muḥammad Qārī al-Harawī, Mirqāt al-Mafätīh: Sharh Mishkāt al-Mașābīh, vol. 4 (Beirut: Dār al-Fikr, 1992), p. 1296. According to Musa bin Talhah, this hadith is mursal, whereas hadith narrated by Tirmizi from Mu'az is da'if since it was narrated by Hassan bin 'Imarah.

32 Muḥammad ibn 'Abd al-Wāḥid Ibn al-Humām, Fatḥ al-Qadìr, vol. 3 (Cairo: al-Halabi, 1970), pp. 243-4.

33 Mohamad Abdun Nasir, "Islam in Diaspora: Shari'a Law, Piety and Brotherhood at al-Farooq Mosque, Atlanta", Al-Jami'ab: Journal of Islamic Studies, vol. 54, no. 1 (2016), pp. 66-8; M. Amin Abdullah, "Religion, Science, and Culture: An Integrated, Interconnected Paradigm of Science", Al-jami'ab: Journal of Islamic Studies, vol. 52, no. 1 (2014), p. 181. 
commercial crop which promises higher returns to the nation's economic growth. Therefore, it is most appropriate under current circumstances and considering public interest, for agricultural zakat to be extended according to Abu Hanifah's view as what being practiced by the Muslim community in Malaysia regarding the payment of zakat fitrah by using equivalent value.

\section{E. Current Agricultural Economics and the Significance of the Zakat Expansion on Crops in Malaysia}

Based on current agricultural reality in Malaysia, the extension of the type of crops that are compulsory to zakat needs to be reassessed by relevant researcher ties, considering the nature of its activities that bears very lucrative returns, for example commercial agricultures or industries that millions of ringgit as well as land usage exceeding millions of hectares such as palm oil and rubber plantation when compared to paddy alone.

Based on Statistic Information Book, ${ }^{34}$ in 2016 palm oil has topped the rank with the cultivated land spanning of 4,804,037 hectare and production as much as $65,361,271$ metric per tonne, followed by rubber 1,072,920 hectare with production of 673,513 metric per tonne. Meanwhile, in the same year paddy ranks at the third place with the land spanning of 715,301 hectare and production of 3,492,075 metric per tonne.

Meanwhile, the main agricultural exports in Malaysia is palm oil with annual revenues of RM50,696 million in 2014, increased RM11,527 million to RM62,223 million in 2015 and as of 2016, exports for this product has exceeded RM49,487 million. In addition revenues from palm oil, natural rubber crops also bring very good results to its operators with exports amounting to RM4,259 million in 2014 and doubled with RM9,210 million in 2015, and as of 2016, has already recorded a profit of RM7,434 million. ${ }^{35}$ This data is supported by Istikoma et al and Md Mahmudul Alam et al who states that currently Malaysia play vital role in change an agriculture-based to industries, as Eight Entry Point Projects (EPPs) were identified under the Palm Oil National Key Economic Area

34 Jabatan Perangkaan, Buku Maklumat Perangkaan Malaysia (Putrajaya: Jabatan Perangkaan Malaysia, 2017), pp. 3-11.

35 Ibid., p. 3. 
(NKEA) to drive the sector`s growth and its role as a central element of the national economy. ${ }^{36}$

Based on the interviews conducted, zakat collection from paddy cultivation sector continues to register a decrease and was recorded to be the third last in the list ${ }^{37}$ compared to zakat from other properties such as zakat on business, zakat on savings and zakat from personal income which contributed the largest portion of the annual zakat collection. ${ }^{38}$

Based on the paddy crop zakat collection statistics, ${ }^{39}$ the diversity of the paddy zakat collection is due to several factors. Firstly, the area of paddy crop land which is moderate and static which will cause vulnerability in terms of yields, paddy production, and Malaysia economy ${ }^{40}$

In Perlis, the estimated paddy crop land is 52,000 acres followed by Penang and Sarawak respectively with the average of 25,000 acres and 19,000 acres, whereas Terengganu 17,000 acres only. In comparison,

36 Istikoma Abdullah, Qurat-ul-ain Mastoi, and Abdul Rahman Ahmad Dahlan, "The Transformation of an Agriculture to an Industrial-based Economy through Crowd Sourcing in Malaysia", International Journal of Computer Science and Information Technology Research, vol. 3, no. 1 (2015), pp. 37-40; Md Mahmudul Alam et al., "Initiatives and Challenges of Agricultural Crop Sector in East Coast Economic Region (ECER) Development Projects in Malaysia", American-Eurasian Journal of Agricultural \& Environmental Sciences, vol. 12, no. 7 (2012), pp. 925-9.

37 Lowest collection belongs to zakat on paddy followed by zakat on gold and zakat on livestock recorded the lowest. However, this collection differs from one state to another.

${ }^{38}$ Mohd Nazim bin Haji Md Noor (Head of Zakat Unit, Baitulmal Department, Perlis Islamic Religious Council), interview (4 Sep 2012); Zuhaimi Bin Tuan Sembok (Executive Officer for Zakat Assessment, Terengganu Islamic Religious and Malay Customs Council), interview (3 Oct 2012); Malaysian Administrative Modernisation and Management Planning Unit (MAMPU), "Statistik Kutipan dan Bilangan Pembayar Mengikut Jenis Zakat Bagi Tahun 2013 Sehingga 2017”, Malaysia's Open Data Portal, http://www.data.gov.my/data/ms_MY/dataset/statistik-kutipan-bilangan-pembayarmengikut-jenis-zakat-di-negeri-pulau-pinang/resource/e92e78c8-a00a-4a95-b27b0c65b91c697e, accessed 2 Oct 2018.

39 Jabatan Wakaf, Zakat, dan Haji (JAWHAR), "Statistik Kutipan Zakat Seluruh Malaysia", Portal Pengurusan Maklumat Zakat dan Baitulmal Malaysia, http://baitulmal. jawhar.gov.my/zkt_statistik_stat.php, accessed 2 Oct 2018.

40 Md. Mahmudul Alam et al., "Agricultural Vulnerability and Adaptation to Climatic Changes in Malaysia: Review on Paddy Sector", Current World Environment, vol. 8, no. 1 (2013), pp. 3-8. 
the planting area and production of the other crops during the period of five years from the year of 2012-2016, for instance, the fruit crops in Terengganu recorded the planting area at 11,026 acres to 24,815 acres. Similarly to Sarawak with the area of fruit crops increasing constantly from 34,403 acres to 44,996 acres and the production of fruits has recorded the biggest number compared to the other states that are the research subjects of the study which has reached 220,827 tons in the year of 2015.

The state of Sarawak is superiorly well known with the growth of black or white pepper, nearly $98 \%$ of Malaysian pepper production is from Sarawak with total exports for the year 2012 is 18,824 metric tons and increased to 19,748 metric tons in 2014 respectively valued at RM113.2 million and RM120 millions. There is also another commercial agriculture in Sarawak such as coconut with planting area of 23,380 acres to 25,352 acres that are capable of providing higher income compared to only paddy crop.

Secondly, it is due to the number of paddy zakat payer in the states. For instance, the lowest rate of paddy zakat collection is in Sarawak from $26 \%$ of Sarawak's Malay minority and only a total of $8 \%$ work on paddy crop and occurrences of the decreasing in the payment of paddy zakat. Meanwhile, based on the interviews in Terengganu and most of the states perceived that most of the paddy farmers have paid zakat on their paddy crop. Therefore the rate of collections have reached the maximum level and will always maintain or will only have small increments based on the surplus of crops production.

Based on the paddy crop collections scenario, it can be clarified that the agricultural zakat revenue be extended to the profitable commercial crop based on the current economy situation and locality as well as fulfilment of objective of Shariah. Protection of wealth (bif z $u$ al-Mal) can boost the agricultural zakat collections revenue and finally provide benefits to the Muslims economy.

In the expanding the source of agricultural zakat revenue in Malaysia, community's views and perceptions have to be taken into account. Therefore, based on the research findings of Sanep Ahmad and Hairunnizam Wahid and Suhaili Sarif et al, in average 53.8\% community views agreed that agricultural zakat should be expanded to commercial 
crop such as oil palm, fruit crops, rubber, cocoa, vegetables and honey bee. ${ }^{41}$ Whereas, based on the researchers' interview, it is responsibility in managing the state agricultural zakat in expanding of agricultural zakat revenue. It also showed various reactions from the state agricultural zakat administration and the State Mufti Department.

Briefly, there are two different perceptions require the expansion of crop and vice-versa. Majority of the informants including Sabibul Samahah Dato' Seri Haji Hassan bin Haji Ahmad (Mufti of Penang), ${ }^{42}$ Sabibul Samahah Datu Haji Kipli bin Haji Yassin (Mufti of Sarawak), ${ }^{43}$ Roslan bin Isa (Deputy Mufti of Perlis), ${ }^{44}$ Zuhaimi bin Tuan Sembok (Executive Officer for Zakat Assessment, Terengganu Islamic Religious and Malay Customs Council), ${ }^{45}$ Zulhazmi bin Bohari (Executive Officer, Sarawak Baitulmal Fund, Bandar Sri Aman Branch), ${ }^{46}$ and Azhari bin Ahmad (Executive Officer for Dakwah Syara' Consultancy, Collection and Marketing Department, Zakat Management Centre) ${ }^{47}$ are highly agreed that agricultural zakat revenue should be expanded based on maqasid shari ah for the benefit of the recipients. However, Mohd Farid bin Mohd Zainal (Executive for Corporate Information Sector, Selangor Zakat Board) ${ }^{48}$ and Mohd Nazim bin Haji Md Noor (Head of Zakat Unit, Baitulmal Department, Perlis Islamic Religious Council) ${ }^{49}$ did not agree with the above perception.

There are factors that influence the above informants' perspective which encompass the economy of local agricultural industry, current effectiveness of annual collection of zakat on paddy, the strictness in

41 Sanep Ahmad, Hairunnizam Wahid, and Wiyadi Wiyadi, "Potensi dan Cabaran Terhadap Perluasan Sumber Zakat Sektor Pertanian di Malaysia", Benefit: Jurnal Manajemen dan Bisnis, vol. 12, no. 1 (2009), pp. 66-76; Sarif, Kamri, and Madun, “The Impact of Malaysian Islamic Revivalism on Zakat Administration", pp. 40-1.

42 Dato' Seri Haji Hassan bin Haji Ahmad, interview (20 Sept 2012).

43 Datu Haji Kipli bin Haji Yassin, interview (25 Sept 2012).

44 Roslan bin Isa, interview (05 Sept 2012).

45 Zuhaimi bin Tuan Sembok, interview (03 Oct 2012).

46 Zulhazmi bin Bohari, interview (24 Sept 2012).

47 Azhari bin Ahmad, interview (18 Sept 2012).

48 Mohd Farid bin Mohd Zainal, interview (12 Sept 2012).

49 Mohd Nazim bin Haji Md Noor, interview (04 Sept 2012). 
school of Islamic law belief in issuing fatwa and understanding of zakat among the farmers as discussed above.

Apart from the above informants, the need to increase the yield of zakat, is supported by Mufti of Kedah, Mahmood Zuhdi, Mujaini Tarimin, Hailani Muji Tahir, Syed Ghazali Syed Wafa, Ali Baharom and Abdul Rahim Bakar. ${ }^{50}$ Thus, the researcher's opinion leans on maqasid syari ab or the maslabah of the current and local economy, the expanded resources of the agricultural zakat to crops other than paddy, which are thought of as significant to be studied. This is due to the fact that firstly, the acquisition source of the paddy zakat is very much confined, if compared to the main crops and other crops caused by the factor of the uneconomical width of the paddy crops which minimizes paddy yield. Second of all, an unstable acquisition, especially the paddy zakat which is scarce and ranks the last as compared to other asset zakat such as the commercial, income, savings zakat and zakat on Employees Provident Fund (EPF), as the rate of collection of the paddy zakat in most states has reached the maximum level. Thirdly, the expenses of daruriyyat of asnaf are on the increase due to the current growing demands.

Thus, based on the above statement, it is appropriate that the view of Imam Hanifah, and the current growth in economic activities of commercial agricultural as well as community's acceptance and perception to be considered by Shariah Research Panellists, of State's Baitulmal so that a study is carried out to expand agricultural zakat revenue by scrutinizing the validity of arguments and public interest. Then, the result of that study must be extended to the Fatwa Committee to be analysed in terms of feasibility based on section 54 (2), Administration of Muslim Law Enactment of the state ${ }^{51}$ which provides leniency to hold to other opinion apart from definitive Shafi i sect opinion if involves the interest of the majority. This will be similar with the provision of paying zakat fitrah by using equivalent value instead of staple food that is 'ain in nature.

50 Ahmad, Salleh, and Said, "Penerokaan Sumber Baru Zakat di Malaysia”, p. 10.

51 Administration of The Religion of Islam (State of Selangor), Enactment No. 1 of 2003, sec. 54; Administration of The Religion of Islam (State of Penang), Enactment No. 2 2004, sec. 54; Administration of Islamic Religious Affairs (Terengganu), Enactment No. 2 of 2001, sec. 54; Majlis Islam Sarawak Ordinance 2001, Chapter 41, sec. 39. Administration of The Religion of Islam (Negeri Perlis), Enactment No. 4 of 2006, sec. 54. 
If this issue is being thought of a national issue, then it is suggested that it is debated in the Conference of the National Fatwa so that the ruling on zakat on crop can be implemented in a holistic manner can later be adapted in each state.

\section{F. The Realization of Maqasid Shariah in the Revenue Expansion of Commercial Crops}

Doctrines of Islamic law is firm and unchanged, yet its implementation is flexible and dynamics based on current and local values, this factor in line with Islamic legal maxim 'Fatwa changes due to change in time, place and situation'. Appreciation on a particular Islamic law has to be holistic, that is embodies both literal and objective understanding. The objective of Shariah on mankind is to safeguard five elements, namely; to preserve the religion, soul, mind, lineage and property. ${ }^{52}$

Islamic law preserves these five elements in two ways; firstly, determining rulings that can establish and maintain its existence (jalbu al-masalib) and secondly, preventing anything that can destroy or harm those interests (dar'u al-mafasid). Sufi Hasan Abu Talib added the third and fourth way, namely blocking bad interests (Sadd al-dharai') and the passage of time (taqhayyur al-zaman). ${ }^{53}$

There are few elements in commercial crops which give rise to public interests (maslahah ammah) towards the growth of Muslim community's economy especially in Malaysia if expansion on crop revenue is carried out apart from paddy crop, namely:

\section{Maqsad The Element of Wealth}

Al-Qardawi stated that wealth as the reason for obligation in paying zakat for crops that are not stated in the nas (a verse from the alQur'an or hadith used as a foundation for Islamic law), as the obligation for zakat on employment property which uses the qiyas instrument of $85 \mathrm{~g}$ gold to be equivalent to RM14,772 (the price of gold in 2018). Ibn 'Abbas, al-Hasan and Qatadah, 'Ata', al-Suddi, and Ibn Abi Laila are of

52 Faried Kurnia Rahman et al., "Maqashid al-Shari'ah-Based Performance Measurement for the Halal Industry", Humanomics, vol. 33, no. 3 (2017), pp. 357-70.

53 Șūfì Hasan Abū Ṭālib, Tathìq al-Sharīah al-Islāmìyah fì al-Bilād al-'Arabìyah (Cairo: Dār an-nahḍah al-'arabiyyah, 1986), pp. 37-9. 
the opinion that reason for zakat is specific to those who possess wealth as what Allah said in Qur'an, 2: 219; "And they ask you what they should spend. Say, The excess (beyond needs)". ${ }^{54}$ Islamic scholars interprets this sentence as Spend the excess of your property. People who have excess property consist of those who have enough wealth for themselves as well as those they support.

While hadith narrated by Mu `a Ibn Jabal where he was sent to Yaman and was instructed by Prophet to take the properties of the rich and distributed to the poor "Zakat to be taken from the wealthy and to be given to the poor". ${ }^{55}$ Hanafiyyah scholars stated that this hadith is specific to rich people who fulfilled the nisab and have excess for themselves and their family are those who must pay zakat, ${ }^{56}$ which clearly indicates that commercial crop operators such as oil palm, rubber and coconut fall under the category of people subjected to the obligation of agricultural zakat compared to paddy cultivators due to the fact that their income is so sizeable that their products are listed as the main export of the country as compared to paddy revenue. Al-'Aini also supports the above hadith by stressing that zakat is specific to the rich people "There is no charity except for the rich". ${ }^{57}$

There are also athar (the narrations of the companions), namely interpretation by 'Umar al-Khattab due to current economic at that time by expanding zakat revenue apart from the existing nas such as imposing zakat on the horse used for commercial purposes and not as war horse as in the time of the Prophet and did not become the symbol of wealth. ${ }^{58}$ Similarly, expansion on crop yield occurred during the ruling of Khalifah 'Umar by expanding the assessment of agricultural zakat on legumes

54 Qur'an, 2: 219.

55 Bukhari, Sahih Al-Bukhari. Kitab al-Zakat, Bab Wujub al-Zakat, Hadith No. 1395, sahih hadith.

56 Ahmad ibn 'Abd al-Rahman al-Banna Sa'ati, Al-Fath al-Rabbani Li Tartib Musnad al-Imam Ahmad Ibn Hanbal al-Syaybani Ma'a Syarbih Buluqh al-Amani Min asrar al-Fath al-Rabbani, vol. 9 (Cairo: Dar al-Shihab, 1983), p. 103.

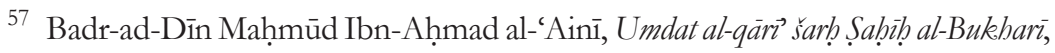
vol. 7 (Beirut: Dār Iḥyā’ at-Turāt al-'Arabī, 1980), p. 294.

58 Sa'ati, Al-Fath al-Rabbani Li Tartib. See Bukhari, Sabih Al-Bukhari. Kitab alZakat, Bab Laisa 'Ala al-Muslim Fi Farasihi Wa Qulamihi Sadaqah, Hadith No. 1394. A sahih Hadith. 
such as nuts ('adas), white nut (bumus) and cotton (kutniyyah) which were subjected to zakat as well as olive based on the situation an current need at that particular time.

Thus the decision of the Islamic law regard to the expansion of revenue of commercial crops should refers to the suitability and consider the socio-economic development which take place in the community. This view is supported by Wan Zulkifli et al. ${ }^{59}$

\section{Maqsad Profitable (Al-Nama)}

The method of al-nama or profitable is one of the condition that need to be complied upon in zakat. ${ }^{60} \mathrm{Al}$-Qardawi stressed that every profitable property whether hakiki (profitable in absolute sense means the property increases or multiplies via appreciation or business) or takdiri (profitable in the sense of fate means the property has the ability to increase under the management of its owner or agent) is the fund for zakat even though Prophet did not directly mention about obligation of zakat on properties. ${ }^{61} \mathrm{He}$ also explains how a property can be considered prosperous or not based on the attribute that the property does dot depreciate and has the ability to multiply whether via business means or breeding. ${ }^{62}$ The nation's main crop and commercial crop provide a very sizeable income and the ever increasing land area shows the government interest towards crops that are able to bear lucrative revenue to the National Gross Domestic Product (GDP).

\section{Maqsad That Benefit The Poor}

Sanep Ahmad and Hairunnizam Wahid are of the opinion that in analysing reason for the obligation of zakat on properties being argued by looking at the method that benefits the poor or the beneficiaries (asnafs), for example, there are two reasons for obligation of zakat or there exists disagreement among the Islamic scholars on the obligation

59 Wan Zulkifli et al., "Suitability of the Zakah Fatwa with Economics Society in Terengganu, Malaysia”, Journal of Applied Sciences Research, vol. 8, no. 5 (2012), p. 2519.

60 Mahmood Zuhdi Abd Majid, "Sumber-Sumber Zakat: Huraian Berasaskan Realiti Semasa di Malaysia”, Jurnal Syariah, vol. 3, no. 1 (1995), pp. 56-63.

61 Al Qardawi, Fiqh al Zakah, p. 145.

${ }^{62}$ Ibid., p. 143. 
of zakat, then in this case, the opinion chosen is the one that benefit the poor and hard-core poor the most. ${ }^{63}$ In our opinion, even though Maliki and Shafi i sect limit the agricultural zakat to staple food only, and other profitable crops to be considered under the category of zakat on income, as practiced by Selangor Zakat Board, zakat for income (al-mal al-mustafad) is imposed on revenue for crops such as rubber, oil palm, coconut and other main industrial crops of Malaysia. Zakat on income covers all kind of wages, remuneration, payment, rental or revenue acquired from work or efforts performed whether in continuous basis or part time or independent work.

From economic perspective, if comparison is made between commercial crops imposed with income zakat (al-mal al-mustafad) the annual rate is $2.5 \%$ whereas for agricultural zakat the rate stood at $10 \%, 5 \%$ or $7.5 \%$, and zakat is compulsory for each harvests. Logically, agricultural zakat will bear multiple revenue and would benefit the asnafs.

Maqasid in determination of zakat on crops is fertile crop that bears wealth to the farmers or planters and exceed the current nisab by considering farmers' interest as well as those being supported by them and it is the reason for maqasid shariah that obligation of zakat to be imposed on all type of crops and not limited to paddy crop only, as what is currently practiced in Malaysia.

\section{G. Concluding Remarks}

The conclusion that can be drawn from the discussion made in this paper is maqasid syari ab in expanding revenue of zakat on crop to commercial crops in such as oil palm, rubber and coconut based on arguments used by Imam Hanafi which accurately concur with the generality of nas (a verse from the al-Qur'an or hadith used as a foundation for Islamic law) as debated by al-Qardawi. The reason for this revenue expansion is due to the presence of elements of wealth, profit and benefits to the beneficiaries (asnaf) based on the current economic statistics for the year 2012 to 2017. Similarly, the analysis on community's and informant's perceptions in this study who are of the opinion that it is appropriate to expand the revenue of zakat on crop to other crop apart

63 Ahmad, Wahid, and Wiyadi, "Potensi dan Cabaran Terhadap Perluasan Sumber Zakat Sektor Pertanian di Malaysia”, pp. 66-76. 
from paddy crop only. Hence, expanding the revenue from agricultural zakat to commercial agricultural sector is thought to be very appropriate based on current economic situation.

\section{Acknowledgements}

The authors are gratefully acknowledge the Ministry of Education (MoE) for funding this research project through the Fundamental Research Grant Scheme (FRGS), reference code [USIM/FRGS/ FSU/055002/50919], This study also expresses its appreciation to the Faculty of Shariah and Law, Universiti Sains Islam Malaysia (USIM) and The World Fatwa Management and Research Institute (INFAD), International Fatwa and Halal Centre (iFFAH) for their cooperation. 


\section{BIBLIOGRAPHY}

Abdul Rahman, Muhamad Firdaus et al, "The Inconsistency Of Assessing Agricultural Zakat", Global Journal Al Thaqafah, vol. 4, no. 1, 2014, pp. 17-31 [https://doi.org/10.7187/GJAT512014.04.01].

Abdullah, Istikoma, Qurat-ul-ain Mastoi, and Abdul Rahman Ahmad Dahlan, "The Transformation of an Agriculture to an Industrialbased Economy through Crowd Sourcing in Malaysia", International Journal of Computer Science and Information Technology Research, vol. 3, no. 1, Research Publish Journals, 2015, pp. 34-41.

Abdullah, M. Amin, "Religion, Science, and Culture: An Integrated, Interconnected Paradigm of Science", Al-Jami'ah: Journal of Islamic Studies, vol. 52, no. 1, 2014, pp. 175-203 [https://doi.org/10.14421/ ajis.2014.521.175-203].

Administration of Islamic Religious Affairs (Terengganu), Enactment No. 2 of 2001.

Administration of The Religion of Islam (Negeri Perlis), Enactment No. 4 of 2006.

Administration of The Religion of Islam (State of Penang), Enactment No. 22004.

Administration of The Religion of Islam (State of Selangor), Enactment No. 1 of 2003.

Ahmad, Musa, Arifin Md Salleh, and Abdullah Said, "Penerokaan Sumber Baru Zakat di Malaysia", presented at the Persidangan Zakat dan Cukai Peringkat Kebangsaan, Selangor, 22 Apr 2007.

Ahmad, Sanep, Hairunnizam Wahid, and Wiyadi Wiyadi, "Potensi dan Cabaran Terhadap Perluasan Sumber Zakat Sektor Pertanian di Malaysia", Benefit: Jurnal Manajemen dan Bisnis, vol. 12, no. 1, 2009, pp. 1-12 [https://doi.org/10.23917/benefit.v12i1.1281].

Al Qardawi, Yusuf, Figh al Zakah, Beirut: Muassasah al-Risalah, 1997.

Alam, Md Mahmudul et al., "Initiatives and Challenges of Agricultural Crop Sector in East Coast Economic Region (ECER) Development Projects in Malaysia", American-Eurasian Journal of Agricultural \& Environmental Sciences, vol. 12, no. 7, 2012, pp. 922-31. 
Alam, Md. Mahmudul et al., "Agricultural Vulnerability and Adaptation to Climatic Changes in Malaysia: Review on Paddy Sector", Current World Environment, vol. 8, no. 1, 2013 [http://dx.doi.org/10.12944/ CWE.8.1.01].

Baihaq̄ī, Aḥmad Ibn-al-Husain al-, As-Sunan al-Kubrā, vol. 4, Beirut: Dār al-Kutub al-'Ilmìya, 1994.

Bakar, Mahyuddin Haji Abu and Abdullah Haji Abd.Ghani, "Towards Achieving the Quality of Life in the Management of Zakat Distribution to the Rightful Recipients (The Poor and Needy)", International Journal of Business and Social Science, vol. 2, no. 4, 2011, pp. 237-45.

Bukhari, Muhammad ibn Ismāîil al, Sahih Al-Bukhari, Damascus: Dār ibn Kathīr, 1993.

Dāraquṭni, 'Alī ibn 'Umar, Sunan al-Dāraqutni, vol. 2, Jeddah: Dār alAndalus al-Khaḍrā’ lil-Nashr wa-al-Tawzī', 2000.

e-Fatwa, http:/ / www.e-fatwa.gov.my/fatwa-negeri/zakat-komoditiutama-seperti-kelapa-kelapa-sawit-getah-lada-hitam-nenas-dan-lainlain., accessed 6 Dec 2018.

Hajar Al-asqalani, Ahmad bin 'Ali, Fath al-Bari bi-Syarah Sabih al-Bukhari, vol. 3, Beirut: Dar al-fikr, 1993.

al-Harawī, Alī ibn Sulțān Muhammad Qārī, Mirqāt al-Mafātīḥ: Sharḥ Mishkeàt al-Mașäbīh, vol. 4, Beirut: Dār al-Fikr, 1992.

Haythamī, Nūr al-Dīn 'Alī ibn Abī Bakr, Majma' az-Zawaid wa Manba' al-Fawaid, Cairo: Maktabat al-Qudsī, 1994.

'Ainī, Badr-ad-Dīn Mạ̣mūd Ibn-Aḥmad al-, Umdat al-qär’ šarh Șahīh alBukharì, vol. 7, Beirut: Dār Ihyā̄' at-Turāt al-'Arabī, 1980.

al-Shafi'i, Muhammad ibn Idris, Al-Umm, vol. 2, Beirut: Dar al-Ma arif, 1973.

Ibn al-Humām, Muḥammad ibn 'Abd al-Wāhịid, Fatḥ al-Qadìr, vol. 3, Cairo: al-Halabi, 1970.

Jabatan Perangkaan, Buku Maklumat Perangkaan Malaysia, Putrajaya: Jabatan Perangkaan Malaysia, 2017.

Jabatan Wakaf, Zakat, dan Haji (JAWHAR), 'Statistik Kutipan Zakat Seluruh Malaysia', Portal Pengurusan Maklumat Zakat dan Baitulmal 
Malaysia, http://baitulmal.jawhar.gov.my/zkt_statistik_stat.php, accessed 2 Oct 2018.

al-Jawzīyah, Muhammad ibn Abī Bakr Ibn Qayyim, I Yam al-Muwaqqi in an Rabb al-'Alamin, ed. by Muhammad Muhyu al-Din 'Abd 'Aziz, Beirut: Dar al-Fikr, 1977.

Kasri, Rahmatina A., "Maqasid al-Shariah and Performance of Zakah Institutions", Kyoto Bulletin of Islamic Area Studies, vol. 9, 2016, pp. $19-41$.

“Kelapa Sawit Kena Zakat Tanaman?”, al-abkam.net 1434, 24 Sep 2008, http://www.al-ahkam.net/home/content/sj-11-0218-kelapa-sawitkena-zakat-tanaman, accessed 30 Dec 2018.

Khafidz, Hasanah Binti Abd, "Asnaf Lapan: Kesan Nilai Semasa dan Setempat dalam Pentafsirannya di Malaysia", PhD. Dissertation, Kuala Lumpur: University of Malaya, 2006.

Lembaga Zakat Selangor, "Kiraan Zakat Padi”, Lembaga Zakat Selangor, 2018, https://www.zakatselangor.com.my/keputusan-syariahzakat/kiraan-zakat-padi/, accessed 14 Nov 2018.

Mahmood Zuhdi Abd Majid, "Sumber-Sumber Zakat: Huraian Berasaskan Realiti Semasa di Malaysia", Jurnal Syariah, vol. 3, no. 1, 1995, pp. 56-63.

Mājah, Muḥammad ibn Yazīd Ibn, Sunan Ibn Mâjah, Cairo: Dar Ibn alJawzi, 2011.

Majelis Agama dan Istiadat Melayu Perlis, Buku Panduan Zakat, Perlis: Baitulmal MAIPs.

Majelis Agama Islam dan Istiadat Melayu Perlis, “Zakat Tanaman”, Majlis Agama Dan Istiadat Melayu Perlis, https:/ /www.maips.gov.my/index. php, accessed 11 Sep 2018.

Majlis Islam Sarawak Ordinance 2001, Chapter 41.

Malaysian Administrative Modernisation and Management Planning Unit (MAMPU), "Statistik Kutipan dan Bilangan Pembayar Mengikut Jenis Zakat Bagi Tahun 2013 Sehingga 2017”, Malaysia's Open Data Portal, http://www.data.gov.my/data/ms_MY/dataset/ statistik-kutipan-bilangan-pembayar-mengikut-jenis-zakat-di-negeripulau-pinang/resource/e92e78c8-a00a-4a95-b27b-0c65b91c697e, 
accessed 2 Oct 2018.

Myibbin, Mohd Rifqi et al., "Zakat Pertanian dalam Konteks Malaysia: Satu Kajian dan Penilaian Semula", in Islam: Past, Present and Future, ed. by Ahmad Sunawari, Long Jaffary, and Awang Kamaruddin Salleh, Bangi: Universiti Kebangsaan Malaysia, 2004.

Nasā’̄, Aḥmad ibn Shu'ayb, Sunan al-Nasā’̄, vol. 5, Beirut: Dar al-Ma’rifah, 1992.

Nasir, Mohamad Abdun, "Islam in Diaspora: Shari'a Law, Piety and Brotherhood at al-Farooq Mosque, Atlanta", Al-Jami'ah: Journal of Islamic Studies, vol. 54, no. 1, 2016, pp. 59-93 [https://doi. org/10.14421/ajis.2016.541.59-93].

al-Naysaburi, Imam Muslim ibn al-Hajjaj, Saḩị̆ Muslim, Liechtenstein: Jam‘īyat al-Maknaz al-Islāmī, 2000.

Nor, Abi Musa Asa'ari Mohamed, “Transformasi dalam Sektor Pertanian dan Industri Asas Tani”, presented at the Halatuju Sektor Pertanian dan Industri asas Tani, Selangor: Kementerian Pertanian dan Industri Asas Tani, 12 Aug 2004.

Rahman, Faried Kurnia et al., "Maqashid al-Shari'ah-Based Performance Measurement for the Halal Industry", Humanomics, vol. 33, no. 3, 2017, pp. 357-70 [https://doi.org/10.1108/H-03-2017-0054].

Rahman, Muhamad Firdaus Ab and Muhammad Amanullah, "The Implementation of 'Temporary Endowment in Kuwait", Al-Jami'ah: Journal of Islamic Studies, vol. 54, no. 2, 2016, pp. 477-503 [https:/ / doi.org/10.14421/ajis.2016.542.477-503].

Sa'ati, Ahmad ibn 'Abd al-Rahman al-Banna, Al-Fath al-Rabbani Li Tartib Musnad al-Imam Abmad Ibn Hanbal al-Syaybani Ma'a Syarbib Buluqh alAmani Min asrar al-Fath al-Rabbani, vol. 9, Cairo: Dar al-Shihab, 1983.

Șan‘ānī, al-Amīr Muhammad Ibn-Ismāīil al-Jaman̄̄, Subul as-Salām, vol. 2, Cairo: al-Maktaba at-Tighārijja al-Kubra, 1953.

Sarif, Suhaili, Nor Azzah Kamri, and Azian Madun, "The Impact of Malaysian Islamic Revivalism on Zakat Administration", International Journal of Nusantara Islam, vol. 1, no. 1, 2013, pp. 36-53 [https:// doi.org/10.15575/ijni.v1i1.35].

al-Sayuti, Jalaluddin Abd Rahman, Al-Ashbah wa al-Nazair fi Qawa'id wa 
Furu' Fiqh al-Shafi'iyah, Riyadh: Maktabah Nazar Mustafha al-Baz, 1997.

al-Sharbīnī, Muhammad Khațīb, Mughni al-Muḥtäj ilá Ma'rifat Ma'ānì alfāx. al-Minhäj., vol. 2, Beirut: Dār al-Kutub al-'Tlmīyah, 2009.

al-Sijistān̄̄, Abū Dā'ūd Sulaymān ibn al-Ash'‘th, Sunan Abu Dawnd, Beirut: Mu'assasat al-Kutub al-Thaqafiyah, 1988.

SS Mufti Jabatan Mufti Negeri Perlis, Kompilasi Keputusan Fatwa, Perlis: Jabatan Mufti Negeri Perlis, 2018.

Tabung Baitulmal Sarawak, "Tanam-Tanaman”, Tabung Baitulmal Sarawak, https://www.tbs.org.my/www/?page=97, accessed 31 Aug 2017.

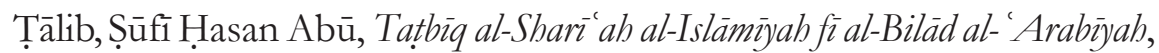
Cairo: Dār an-Nahụah al-'Arabiyyah, 1986.

Wan Zulkifli et al., "Suitability of the Zakah Fatwa with Economics Society in Terengganu, Malaysia", Journal of Applied Sciences Research, vol. 8 , no. 5, 2012, pp. 2518-30.

“Zakat Pertanian”, Zakat Pulau Pinang, http://www.zakatpenang.com/ zpp/index.php/2013-06-30-10-54-31/jenis-zakat/zakat-pertanian, accessed 2 Sep 2017. 